\title{
Research on the Credit Guarantee System of Small and Medium-sized Enterprises in China
}

\author{
Yuxi Zhu ${ }^{1, *}$ \\ ${ }^{1}$ Wuhan International Trade College, Wuhan, Hubei 430205, China \\ ${ }^{*}$ Corresponding author. Email:13277991778@163.com
}

\begin{abstract}
With the widespread of the reform and open policy in China, the small and medium enterprises (SMEs) are becoming one of the vital parts of the national economy. Currently, Chinese credit guarantee system for SMEs has made some achievements, such as the increasing number of our country SME credit guarantee institutions, such as the larger business scale, the deepening extent of market-oriented and the higher ability to manage risks, which effectively supported the development of SMEs. Meanwhile, there are still lots of defects. Based on the SME credit guarantee system in China and foreign countries theoretical summarizing as well as relevant theory of the principles of economics, a profound understanding of China's development of SME credit guarantee system is significant. Subsequently, it is to reference the developed countries to develop the SME credit guarantee system for the successful experience, such as United States and Japan. Finally, it is to put forward the way to improve the credit guarantee system for SMEs in our country from the external environment and internal mechanism.
\end{abstract}

Keywords: SMEs, credit guarantee system, foreign experience

\section{INTRODUCTION}

SME credit guarantee system, as a vital part of the state's financial support policy for SMEs, needs special laws and regulations to regulate it. In this regard, China's current laws and regulations concerning SME credit guarantee industry mainly include the company law, the guarantee law and the SME Promotion Law. With the departmental regulations and local laws and regulations made by local governments according to relevant policies, among them, the company law does not provide special provisions to guarantee institutions. The object of adjustment of the guaranty law is the nonprofessional guarantee activities of general enterprises and institutions or natural persons, with a focus on protecting the interests of creditors. The market access and exit, professional scope and type, qualification of employees, financial and internal control system, industry self-discipline and government regulation have not been clearly stipulated. At present, the domestic legal system construction for the development of the protection guarantee industry is obviously lagging behind the development of the industry. Therefore, the market access, business operation and market exit process of the guarantee institutions are in a laissez faire state, which seriously hampers the SME credit guarantee system.

Currently, the imperfect credit system of SMEs in China is mainly manifested in: First and foremost, the credit investigation system of SMEs is developing slowly. The credit registration and consultation system of central banks has just been established in China's SME credit reporting system, and the development of commercial credit information system is behindhand. Then, the credit evaluation system of SMEs is not perfect. Under the existing system, only a few specialized and authoritative large credit rating agencies, such as Dagong international credit rating, are currently available.

At the same time, when commercial banks conduct credit rating for SMEs, they adopt the same standards as big enterprises, rather than theories and methods to determine the credit rating of SMEs according to international practice. These problems make the rating level lacking pertinence and inevitably break away from the reality of enterprises. Some SMEs with good prospects and good performance can not get loan preferences because they fail to get the credit level they need. However, some SMEs without prospects for development are full of money and get bank loans, which will bring greater business risks to SME credit guarantee institutions and cooperative banks.

The government gives weak support to the development of SMEs credit guarantee institutions, which makes it difficult to effectively release the policy intent and magnifying effect of supporting SMEs. Taking the tax preference policies commonly used by 
countries (regions) as an example, China only exempted the three year business tax from the guarantee income of the guarantee institutions that are included in the pilot scale of the SME credit guarantee system. There are no other tax concessions.

\section{FOREIGN EXPERIENCE OF SME CREDIT GUARANTEE SYSTEM}

\section{A. The SMEs credit guarantee system in the US}

The guarantee system of SMEs in the United States has been established earlier and has some representativeness. Its credit guarantee system has become a model for all countries to follow the example of strict design, scientific structure, clear responsibilities, standardized operation and remarkable effect. In 1953, the US Congress passed the small business act and the small business finance act, based on these two bills. The United States, the Senate and the Senate set up the SME committee respectively, and at the same time set up the Small Business Administration. SBA is an independent functional department directly affiliated to the government. According to the provisions of the two act, SBA has four basic functions: first, it is responsible for the operation of the SME credit guarantee system, and the guarantee way helps small businesses obtain loans from commercial banks; the two is to ensure that small businesses get government procurement; the three is to subsidize communities to establish small business loan centers and other institutions to help minority nationalities, women and veterans to establish and run small businesses. The four is to provide free services to small businesses such as SME planning, account management, cash flow analysis, loan and budgeting. The main task of developing small business credit guarantee business is to provide guarantee for SME financing through government support and support the development of SMEs. At present, SBA aims at supporting the development of SMEs. SBA has $\$ 45$ billion in commercial loans, loan guarantees and venture capital, plus $\$ 5$ billion in disaster relief loans. It is the largest financial pillar of SMEs in the United States.

Structurally speaking, the SMEs credit guarantee system in the United States is based on the credit rating system, with two bills as the legal guarantee. The first level guarantee system, which is directly guaranteed by the small business administration and its branches in the whole country, is currently in the United States. There are three sets of credit guarantee systems for SMEs in the US: the National SME credit guarantee system directly operated by the federal Small and medium enterprises department, the regional professional guarantee system operated by local governments, and the community guarantee system. Among them, the national credit guarantee system is the main form. The regional credit guarantee system is subsidiary.

With regard to the operation framework of the SME credit guarantee system in the United States, in term of the industrial policies of the government and the provisions of the small business law. SBA is responsible for managing the execution and completion of the plan, and is examined by the congressional hearing. The federal government will inject capital in time. There are no quantitative restriction that chooses cooperative banks to carry out direct guarantee and credit guarantee. The banks choose to cooperate with the government to share the risk on the basis of voluntary principle. The former government does not actually invest in it, and the cooperative banks decide the loan guarantee independently within the credit line, and the guarantee fee is turned over to SBA. After the loss occurs, the bank applies to the government guarantee agency to make compensation for the SBA. After the application is examined, the proportion is compensated according to the prescribed proportion and the right to recover debts from the enterprise is obtained. This guarantee system can enhance the sense of responsibility of the cooperative bank, it partly relieves the government's financial pressure. But on the one hand, SBA only requires enterprises to provide a certain amount of collateral, and lack effective control means. On the other hand, the cooperative banks only share the risk of $20 \% \sim 30 \%$, and its income is asymmetric.

In addition to the national small business credit guarantee system directly operated by SBA, there are special credit guarantee systems for SMEs in the United States. Because of the different regional conditions, the regional professional guarantee system has its own characteristics. The export credit guarantee system mainly helps the SMEs in California to expand their exports, and adopts the cooperation mode of government funded and cooperative banks. To sharing the risk of bank loans, banks not only focus on the cash flow of small businesses, but also focus on the future earnings of small businesses, so that SMEs can become stable customers of banks. SMEs have little demand for the guarantee system of community small and mediumsized enterprises. Their main role is to help the poor in the community to get rid of difficulties through the establishment of SMEs. In recent years, the development of the American guarantee industry is characterized by commercialization and specialization. Two main types of commercial guarantee: one is the mortgage Guarantee Corporation. The main purpose is to issue financial guarantees for personal mortgages: the other is the bond Guarantee Corporation, which provides protection to the holders of common bonds and other bonds, and guarantees timely payments of principal and interest. Specialization is manifested in the scope of the guarantee agencies in the United States, 
which are concentrated in a specific area. The industry distinction is very clear. In China, the high-tech financing guarantee business, which is very popular in China, is engaged in professional Vc firm in a clear division of labor.

\section{B. SME credit guarantee system in Japan}

Japan is the first country in the world to build a SME credit guarantee system. The guarantee system of Japanese SMEs is a two level credit guarantee system, which is comprised of two interrelated subsystems: the credit guarantee association and the credit insurance public library. The credit guarantee association consists of 1 national credit guarantee associations and 52 local credit guarantee associations, with more than 160 branches. The Federation of national credit guarantee associations belongs to the industry management association. It is mainly responsible for the unified definition and supervision of the credit guarantee service standards and the business scope of the market participants. The local credit guarantee associations independently provide credit guarantee services to SMEs in the region and provide financial and business consulting services to SMEs.

The Credit insurance public library includes two aspects: one is to provide reinsurance for the credit guarantee service of the Credit Guarantee Association; the two is to provide low interest loans for the credit guarantee association. There is only one credit insurance public Library in the country, which has direct business relationship with 52 local credit guarantee associations. The credit insurance public library does not directly provide guarantee for SMEs. It is for the guarantee of the regional SME Credit Guarantee Association. The credit insurance public library can bear $70 \%$ of the general guarantee, $80 \%$ of the unsecured guarantee, and $40 \%$ of the insurance guarantee fee paid by the credit guarantee association to the insurance public library. After the compensation occurs, the insurance public library will pay $70 \%$ of the insurance premium to the credit guarantee association, if the debt is recovered after compensation. The credit guarantee association returns $70 \%$ of its insurance to the insurance public library. The credit insurance public library is responsible for providing insurance and loans to the surety debt guaranteed by the credit guarantee association. In fact, it provides re guarantee. Its funds are allocated by the government and supervised by the government. The local credit guarantee association is responsible for providing full guarantee for SMEs, that is, the $100 \%$ guarantee. Parts of funds are donated by the small and medium enterprises financial public libraries, such as local governments, public associations and financial institutions. Among them, the proportion of donation funds from financial institutions is relatively large. The other part is borrowed funds, mainly the credit insurance public library and local finance, which are guaranteed by low interest loans. This diversified fund constitutes a guarantee for the stability and scale of the guarantee fund.

\section{EXPERIENCE AND ENLIGHTENMENT OF FOREIGN SMES CREDIT GUARANTEE SYSTEM}

The development process and mode of SME credit guarantee system in different countries are different. But after decades of development, with the development of its market system and the development of financial system, a relatively mature model has been formed. Summarizing these successful experiences can bring useful enlightenment to explore and establish a credit guarantee system for SMEs in China's socialist market economy.

\section{A. Giving full play to the role of the government}

The purpose of establishing credit guarantee system for SMEs is to improve the financing capacity of SMEs, such as increase employment, tax revenue and earn foreign exchange through exports. Therefore, governments regard their support for the development of SMEs as their responsibilities, and become the main drivers of SME credit guarantee system. There are two aspects.

On the one hand, the funds of SME credit guarantee institutions mainly come from government financial support. The establishment and operation of guarantee institutions require a certain amount of funds. There are two types of funds for foreign SMEs credit guarantee institutions: one is the total investment by the government; the two is the government funded as the main body, and the financial institutions and social organizations jointly subsidized. Especially in most countries in Europe, the credit guarantee fund is difficult to maintain without the support of the government. However, under the premise of policy investment, commercial management is generally adopted to achieve the policy objectives. With the backing of national financial resources, it is beneficial to the enlargement of the number of guarantee funds and the extension of the scope of guarantee, so that the guarantee institutions can operate more effectively.

On the other hand, the SME credit guarantee plan has clear policy objectives. The government takes advantage of the SME credit guarantee system to embody its policy intention, guides the social resources to achieve optimal allocation, and promotes economic growth and development. Therefore, the guarantee programs of various countries clearly stipulate the scale and nature of the guarantee objects, which are mainly used to support those who can't get loans from normal channels. The development of SMEs, or some special supporting objects, is a clear provision for the secured enterprises, which is also conducive to reducing the risk 
of guarantee and creating a good market environment for SMEs that really need help.

\section{B. Paying attention to risk diversification and control}

SME credit guarantee is targeted at small and medium enterprises. Most of these enterprises are weak in credit background and are at a disadvantage in terms of scale and competitive position. SME credit guarantee is a shared risk that banks are unwilling to take. This determines that the SME credit guarantee industry is a highly professional and high-risk industry. All countries stress the importance to the decentralization and control of credit guarantee risks of SMEs, and take various measures to reduce risks.

1) Stipulating the relevant indicators: In order to control risks, all countries should make clear provisions on the relevant indicators of credit guarantee in the relevant legal system, including the limits on credit guarantee amount, guarantee amplification ratio, guarantee loan period, annual guarantee rate and guarantee ratio.

2) Strict examination and approval system: It is necessary to establish strict credit guarantee plan management system and approval system of guarantee items, so as to standardize the guarantee procedure.

3) Implementing risk constraints on enterprises: It is a need to implement strict credit approval system for credit enterprises, set up information archives for SMEs, and establish specialized agencies to enhance the accuracy of credit pre - side and reduce the probability of default; when necessary, owners can be required to provide personal property collateral so as to increase owners' responsibilities.

4) Establishing a re-guarantee system: It is also necessary to establish a re-guarantee mechanism for SME credit guarantee, provide the final risk protection with the government credit as the credit guarantee, and make the risk sharing structure more stable.

\section{CONCLUSION}

In conclusion, foreign SME credit guarantee system has developed relatively well, and there are many mature experiences to learn. However, our SME guarantee system has its own characteristics. We should establish and develop a credit guarantee system suitable for China's specific conditions based on the experience of foreign countries and the actual situation of our country. On the one hand, China's SME credit guarantee system should give full play to the role of the government. On the other hand, it should pay attention to risk diversification and control.

\section{References}

[1] Wangsong Xie, Cheng Li. "Notice of Retraction: Comparison and experience: Governmental function in the credit guarantee system of small and medium-sized enterprises", 2011 2nd International Conference on Artificial Intelligence, Management Science and Electronic Commerce (AIMSEC), 2011

[2] Linxiao, "New Supply Side Economic", Springer Science and Business Media LLC, 2017

[3] Mapesela, M.L.E and Strydom, A. H. (2004). Performance management of acadamic staff in South African higher education: A developmental research project. Centre for Higher Education Studies and Development: University of the Free State.

[4] Niven, P.R. (2002), Balanced Scorecard Step by Step, John Wiley \& Sons, New York, NY.

[5] Schobel, K and Scholey, C. (2012). Balanced Scorecards in education: focusing on financial strategies. Measuring Businesss Excellence, 16 (3), 17-28.

[6] Taylor, J and Baines, C (2012). Performance management in UK universities: implementing the Balanced Scorecard. Journal of Higher Education Policy and Management. Vol.34, No.2, April 2012, 111-124.

[7] Valentine, J. C. (2009). Judging the quality of primary research. In H. M.

[8] Wu, Y, H; Lin, Y, K; Chang, C, H. (2010). Performance evaluation of extension education centers in universities based on the balanced scorecard. Elsevier Ltd. All rights reserved. 